\title{
Аюева A.A.
}

\section{Отмена крепостного права в России. Влияние реформы} на правовое положение населения Российской Империи

\author{
Ayueva A.A. \\ The abolition of serfdom in Russia. The impact of reform on \\ the legal status of the population of the Russian Empire
}

В данной статье дается краткая характеристика предпосылок, итогов реформы 1861 года, а также правовое положение населения после отмены крепостного права на основе историко-правового анализа и применения современной научной литературы

Ключевые слова: крепостное право, усадебная осёдлость, выкупная операция

Аюева Анастасия Алексеевна

Студент

Самарский государственный экономический университет

2. Самара, ул. Советской Армии, 141
This article provides a brief description of the assumptions, the outcome of the reform of 1861 and the legal situation of the population after the abolition of serfdom on the basis of historical and legal analysis and application of modern scientific literature

Key words: serfdom, manor residence, a redemption transaction

\section{Ayeva Anastasiya Alekseevna}

Student

Samara state university of economics

Samara, Soviet Army st., 141

Научный руководитель: к.ю.н., доцент Калашникова Е.Б.

Крепостное право зародилось в конце 15 века, а процесс закрепощения крестьян длился на протяжении почти двух веков. Однако в 19 веке была проведена отмена крепостного права, которая изменила не только общественные условия развития страны, но и правовые, тем самым создавая «почву» для создания капиталистического общества. Ликвидация крепостной зависимости крестьян была обусловлена многими социально-экономическими предпосылками, поэтому реформа затянулась на долгие годы и имела свои особенности. Крестьянская реформа имеет судьбоносный характер для всестороннего развития Российской Империи, она является одной из важнейших преобразований эпохи «великих» реформ 60-70 гг. XIX столетия.

Реформа 1861 г., которую господствующие классы были вынуждены провести, чтобы предотвратить крестьянскую революцию, ознаменовала собою вступление России на путь капиталистической аграрной эволюции. Иной эта реформа и не могла быть. 
Император и приближенные к нему слои населения осознавали всё необходимость принятия срочных мер для предотвращения стихийных массовых восстаний крестьян, которые становились всё более и более мощными. Царь 30 марта 1856 г., выступаю перед московскими губернскими и уездными предводителями дворянства, сказал: «Слухи носятся, что я хочу дать свободу крестьянам; это несправедливо,- и Вы можете сказать это всем направо и налево; но чувство, враждебное между крестьянами и их помещиками, к несчастью, существует, и от этого было уже несколько случаев неповиновения помещикам. Я убеждён, что рано или поздно мы должны к этому прийти. Я думаю, что и Вы одного мнения со мной; следовательно, гораздо лучше, чтобы это произошло свыше, нежели снизу» [1, с. 85].

Однако крепостное право не обязательно всегда означало жестокое и безнаказанное отношение помещиков к зависимым крестьянам. В истории России существовали случаи неподобающего отношения к крепостным, но и они рассматривались в дворянских судах и имели определённые санкции. Так, например в 1762 г. помещик Нестеров за жестокие побои, причинившие смерть дворовому человеку, был сослан в Сибирь на вечное поселение. Стоит заметить, что этот случай не является единственным.

Крестьяне же переносили свою зависимость с христианским терпением и достоинством. «Его опрятность, смышленость и свобода... Взгляните на него: что может быть свободнее его обращения! Есть ли и тень рабского унижения в его поступи и речи?» [3].

Среди предпосылок отмены крепостного права основополагающее значение имел и накопленный в первой половине XIX века опыт обсуждения и решения крестьянского вопроса. Указы 1803 года о вольных хлебопашцах и 1842 года об обязанных крестьянах апробировали в законодательстве идеи отмены крепостного права с выкупом земли крестьянами в собственность и неразрывной связи крестьянина с землей.

Большую подготовительную работу для отмены крепостничества провел Государь Николай І. При отмене крепостного права в 1861 году оно распространялось уже лишь на треть крестьян. Однако фактическую личную свободу даровал Александр II. Это и является основой идеи отмены крепостной зависимости в России.

Основные положения данной реформы можно охарактеризовать несколькими тезисами:

- крестьяне получали личную свободу

- право свободно распоряжаться своим имуществом

- помещики сохраняли собственность на все принадлежавшие им земли, однако обязаны были предоставить в постоянное пользование крестьянам «усадебную оседлость», т. е. усадьбу с приусадебным участком, а также и полевой надел «для обеспечения их быта и для выполнения их обязанностей перед правительством и помещиком...» [4].

- выкуп крестьян производился с помощью определённой операции. Её суть заключалась в том, что бывшее зависимое население, посредством ссуды, 
выплачивала в течение 37 лет по 5 \% ежегодно через специальный крестьянский банк выкуп [4, с.157].

В целом реформа была прогрессивной, поскольку открыла простор развитию производственных сил, привела производительные отношения к определенному, хотя и не оптимальному соответствию им [5, с.24-31].

Таким образом, ликвидация крепостного права, которое являлось главной опорой общественного строя России, его административной системы, поставила вопрос о замене прежних институтов и механизмов управления новыми. В связи с этим необходимо было начать преобразование и в других сферах социальной и политической жизни. Это ознаменовало переход к современным формам общественного устройства.

\section{Список используемых источников:}

1. Речь Александра II, произнесенная им 30 марта 1856 г. перед московскими губернскими и уездными предводителями дворянства // Конец крепостничества в России. Документы, письма, мемуары, статьи. М.: Изд-во МГУ, 1994. С. 85.

2. Бутаков Я. Революция сверху // Столетие. 2011. № 38. С. 5.

3. Положения 19 февраля 1861 года о крестьянах, вышедших из крепостной зависимости. М., 1916. 4. Кавелин К.Д. Записка об освобождении крестьян. Русский национальный интерес. Экономическая газета. 2010. С. 157.

5. Захарова Л.Г. Царь-освободитель // Русская история. 2010. №5-6. С. 24-31.

(C) 2015, Аюева A.A.

Отмена крепостного права в России. Влияние реформы на правовое положение населения Российской Империи
(C) 2015, Ayueva A.A.

The abolition of serfdom in Russia. The impact of reform on the legal status of the population of the Russian Empire 